\title{
Biodegradation in simulated soil of HDPE/pro-oxidant/rice husk composites: application in agricultural tubes
}

\author{
Biodegradação em solo simulado de Com- \\ pósitos de PEAD/Pró-oxidante/ \\ Casca de arroz: aplicação em tubetes agrí- \\ colas
}

\author{
Cristiano Cunha Costa ${ }^{1}$,George Ricardo Santana Andrade ${ }^{2}$, \\ Luís Eduardo Almeida ${ }^{1,2}$
}

\footnotetext{
${ }^{1}$ Postgraduate Program in Materials Science and Engineering, Federal University of Sergipe, São Cristóvão, Sergipe, Brazil.

${ }^{2}$ Department of Materials Science and Engineering, Federal University of Sergipe, São Cristóvão, Sergipe, Brazil. e-mail: cristianocunha1982@gmail.com,grsandrade@hotmail.com, lealmeida2009@gmail.com
}

\begin{abstract}
The use of agricultural waste, such as rice husk $(\mathrm{RH})$, for the production of cheap and eco-friendly polymer composites has emerged as a promising field of interest. The aim of this work was the preparation of highdensity polyethylene (HDPE)-based composites reinforced with rice husk and an organic pro-oxidant (EG15) for the production of seedlings tubes. Photodegradation and degradation tests in simulated soil were performed for 90 and 180 days in order to study the decomposition of these composites. The SEM and OM images suggest that degradation of the composites samples was more extensive than the pure HDPE samples, probably because the composites present intense light absorption in the UV range, facilitating the degradation process even before biodegradation begins. In addition, after introducing $\mathrm{RH}$ particles in the polymeric matrix, the mechanical tensile and flexural properties, experienced significant changes, suggesting that the RH particles were homogeneously dispersed throughout the polymer matrix. Finally, the results have demonstrated that HDPE, RH, and EG15 are attractive materials for the design of polymeric composites for the production of seedlings tubes with excellent mechanical properties, being also easily decomposed in the environment once discarded.
\end{abstract}

Keywords: Polymer composites, High-density polyethylene, Rice husk, Biodegradation, Mechanical properties.

\section{RESUMO}

O uso de resíduos agrícolas, como a casca de arroz (RH), para a produção de compósitos poliméricos baratos e eco-amigáveis surge como um campo de interesse promissor. O objetivo deste trabalho foi a preparação de compósitos à base de polietileno de alta densidade (PEAD), reforçados com casca de arroz e um pró-oxidante orgânico (EG15) para a produção de tubetes. Os testes de fotodegradação e degradação em solo simulado foram realizados por 90 e 180 dias, a fim de estudar a decomposição desses compósitos. As imagens de MEV e MO sugerem que a degradação das amostras dos compósitos foi mais extensa do que a amostra de PEAD puro, provavelmente porque os compósitos apresentam intensa absorção de luz na faixa UV, facilitando o processo de degradação mesmo antes da biodegradação. Além disso, após a introdução de partículas de RH na matriz polimérica, as propriedades mecânicas de tração e flexão, experimentaram mudanças significativas, sugerindo que as partículas de RH foram dispersas homogeneamente em toda a matriz de polímero. Finalmente, os resultados demonstraram que o PEAD, RH e EG15 são materiais atraentes para o projeto de compósitos poliméricos para a produção de tubetes com excelentes propriedades mecânicas, sendo também facilmente decompostos no ambiente, após serem descartados. 
Palavras-chave: Compósito polimérico, Polietileno de alta densidade, Casca de arroz, Biodegradação, Propriedades mecânicas.

\section{INTRODUCTION}

The use of plastic materials in agriculture has intensified in recent decades due to their lightweight, low cost, easiness of installation and usage, cheap management, versatility for various applications, and good mechanical properties, as well as the increasing food demand in the world. Polymers such as polyvinyl chloride (PVC), low-density polyethylene (LDPE), high-density polyethylene (HDPE), polypropylene (PP), and ethylene vinyl acetate (EVA) are currently used for different purposes in agriculture, including greenhouse and tunnel covering films, silage covering, shading and protective nets, pipes for irrigation and drainage, soil mulching and solarization films, confection of nets for harvesting and post-harvesting operations, trays, seedling and packaging containers, sacks, pots, strings, and ropes [1-3]. However, the popularization of plastic materials for agricultural purposes has generated great concern due to the increase of adverse effects on the environment. It is estimated that the annual consumption of plastics for agricultural applications is equivalent to approximately 6.5 million tons worldwide, resulting in large amounts of plastic waste [4].

In particular, the use in seedling tubes (containers employed in the production of seedlings) of materials of difficult degradation derived from non-renewable sources has become a serious environmental problem, since they include hydrophobic hydrocarbons resistant to hydrolysis and non-biodegradable [5]. Although there are commercially biodegradable seedlings tubes, they generally do not meet the target dynamics of forest seedling production, since they present low mechanical resistance, cracks, and deformations of the tube structure, making it difficult to handle during application and transport to the field. In this context, a number of researchers have attempted to develop green materials based on biodegradable polymeric composites with a variety of lignocellulosic matrices, such as sisal fibers [6], bamboo fibers [7], recycled cellulose [8], coconut fibers [9], or wood powder [10], among others. In these works, the properties of polyethylene composites with lignocellulosic matrices have shown significant improvements, especially for mechanical tensile and flexural properties, making those composites useful for the various applications [1113].Furthermore, a polar compatibilizer, such as maleic anhydride, can be used in order to improve adhesion between the natural fiber and polymer matrix composites reinforced, from the formation of chemical bonds between the cellulose and matrix polymer, improving the mechanical properties [11].

In this context, rice husk has proven promising for the development of new biodegradable materials as an inexpensive and abundant byproduct of rice processing compatible with the abovementioned applications and with interesting mechanical properties [14]. A few papers exist on the use of HDPE as a polymeric matrix to obtain reinforced composites with rice husk, husk ash, and straw [15-19]. These papers have reported the changes induced on the thermal, morphological, and mechanical properties after the introduction of rice husk. However, to our knowledge, no literature exists on HDPE-based composites with rice husk and the changes in their properties after photodegradation and biodegradation processes in simulated soil.

Thus, the need for cheap polymer-based composites reinforced with particles of natural origin able to withstand environmental adversities (such as solar radiation) with good mechanical properties for use in greenhouses is evident. Also, such materials need to easily decompose in the environment once discarded. However, various commercial HDPE, such as IA59U3 (Braskem), usually presents additives (UV stabilizers and antioxidants), making them refractory to degradation and biodegradation. In this context, the addition of organic pro-oxidants (or pro-degradants), which accelerate the biodegradation of materials, may reduce the polymer composite lifetime. The most commonly used pro-oxidants for degrading polyethylene presents heavy metals, such as cobalt $(\mathrm{Co})$, manganese $(\mathrm{Mn})$ and iron $(\mathrm{Fe})$, in their composition. The concentration of heavy metals in the soil can have harmful effects on the environment and human health [20].On the other hand, organic pro-oxidants are an interesting alternative, once they have oxidative efficiency comparable to the heavy metal-based compounds and they are eco-friendly, as reported by others [21,22].

The aim of this work was the preparation of polymer composites based on HDPE, rice husk, maleic anhydride, and an organic pro-oxidant additive. These composites were exposed to UVA-340 radiation for 90 cycles of $8 \mathrm{~h}$ at $60{ }^{\circ} \mathrm{C}$ and $4 \mathrm{~h}$ of condensation at $50{ }^{\circ} \mathrm{C}$. Then, biodegradation tests were performed in simulated soil for 90 and 180 days. The effects of different biodegradation conditions and compositions on the mechanical, morphological, and optical properties of the composites are reported in this study. 


\section{MATERIALS AND METHODS}

\subsection{Materials}

High-density polyethylene (HDPE), with a melt-flow index of $7.3 \mathrm{~g} / 10 \mathrm{~min}$ and density of $0.96 \mathrm{~g} / \mathrm{cm} 3$, was selected as the polymer matrix and purchased from Braskem (IA59U3). The organic pro-oxidant additive used in this work (EG15) was donated by the TIV Plastic Industry (São Paulo/Brazil). The additive composition was not provided, however, according to the X-ray fluorescence (XRF) analysis, EG15 does not contain any heavy metal. The micronized rice husk (RH) (size distribution between 275 and $512.5 \mu \mathrm{m}$ ) used as the dispersed phase was donated by CerealistaPolisul (Pelotas/Brasil). OREVAC® 18507, a high-density polyethylene functionalized with maleic anhydride (HDPE-MA), was provided by Arkema and used as a coupling agent. All the chemicals were used as received without further purification.

\subsection{Methods}

\subsubsection{Sample preparation and molding}

Prior to the extrusion step, the rice husk particles were dried in a hot air oven (SOLAB Científica, SL $102 / 480$ ) at $120^{\circ} \mathrm{C}$ for approximately $4 \mathrm{~h}$. Then, all the components were manually dry-mixed for homogenization. The compositions and sample codes of the polymeric composites are presented in Table 1 . The extrusion process was performed using a co-rotating twin-screw extruder (Imacon, DRC 30:40 IF) under the following conditions: feed speed of $8.5 \mathrm{rpm}$, screw speed of $117 \mathrm{rpm}$, and a temperature profile of $159^{\circ} \mathrm{C}$ (zone 1), $165^{\circ} \mathrm{C}$ (zone 2), $170^{\circ} \mathrm{C}$ (zones 3 and 4 ), $180{ }^{\circ} \mathrm{C}$ (zones 5 and 6), and $191^{\circ} \mathrm{C}$ (zone 7). Finally, the extrudate was cooled down and cut with a granulator into pellets.

Table 1: Composition (wt\%) and sample identification codes of the polymeric composites evaluated in this study

\begin{tabular}{l|l|l|l|l}
\hline SAMPLE & HDPE-MA & EG15 & RH & HDPE \\
\hline HDPE & 0 & 0 & 0 & $100 \%$ \\
\hline HDPE-EG & 0 & $5 \%$ & 0 & $95 \%$ \\
\hline HDPE-MA-RH & $10 \%$ & 0 & $20 \%$ & $70 \%$ \\
\hline HDPE-MA-RH-EG & $10 \%$ & $5 \%$ & $20 \%$ & $65 \%$ \\
\hline
\end{tabular}

Before injection, the pellets were dried in a hot air oven at $120{ }^{\circ} \mathrm{C}$ for $4 \mathrm{~h}$. Then, the pellets were molded in an injection-molding machine (Battenfeld, HM 45/210DR). The following operating conditions were used: a temperature profile of $150{ }^{\circ} \mathrm{C}$ (feed zone), $170{ }^{\circ} \mathrm{C}$ (compression zone), $190{ }^{\circ} \mathrm{C}$ (head zone), $190{ }^{\circ} \mathrm{C}$ (nozzle), flow rate of $20 \mathrm{~cm} / \mathrm{s}$, volume of $40 \mathrm{~cm}^{3}$, and pressure of $1200 \mathrm{bar}$. The preparation of the test specimens followed the ISO 527-93 guidelines (see Figure 1).

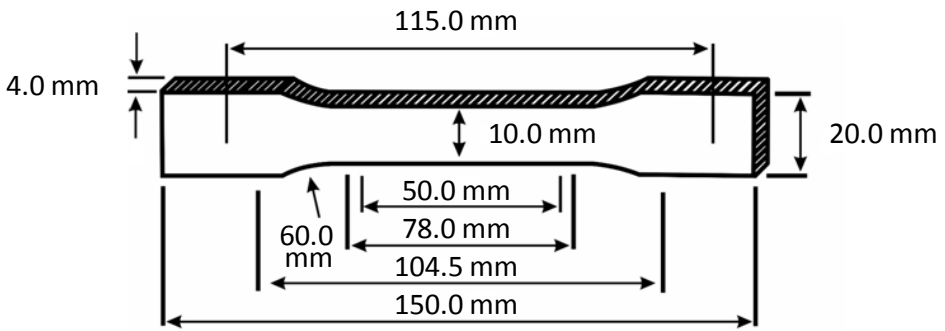

Figure 1: ISO 527-93 guidelines for preparing the specimens.

\subsubsection{Degradation studies using UV irradiation}

For the degradation studies using UV irradiation, the composites were placed in a UV aging chamber (UV Bass model 2011) and the process was carried out in accordance with the ASTM G154-06 and ASTM G15110 standards. As such, in a typical experiment, the composites were exposed to UVA-340 radiation for 90 
cycles of $8 \mathrm{~h}$ at $60{ }^{\circ} \mathrm{C}$ and $4 \mathrm{~h}$ of condensation at $50{ }^{\circ} \mathrm{C}$, over a period of $2160 \mathrm{~h}$. The humidity in those experiments was around $85 \%$.

These calculations were made by estimating the average time that greenhouse seedling tubes are usually exposed to solar ultraviolet radiation under typical conditions of temperature and humidity, accounting to approximately 3 months. It is worth mentioning that the average solar exposure time per day is $\sim 8 \mathrm{~h}$ under UV radiation of $0.89 \mathrm{~mW} / \mathrm{cm}^{2}$. In this study, the lamp intensity was adjusted to $2.7 \mathrm{~mW} / \mathrm{cm}^{2}$.

\subsubsection{Degradation studies in simulated soil}

The aged composites were subjected to biodegradation tests in simulated soil according to an adaptation of the ASTM G160-12 standard. Thus, a wooden box was constructed (dimensions: 1.00:1.00:0.40 m) in order to maintain the temperature and relative humidity constants, as exposed bellow. For the soil preparation, equal parts of soil, horse manure, and sand were sieved with a 10-mesh sieve (Tyler) and then mixed until a homogeneous mixture was obtained. Finally, the simulated soil was aged for 3 months at room temperature and humidity, being turned every 15 days.

For the biodegradation tests, a greenhouse was set up under controlled temperature $\left(30 \pm 2{ }^{\circ} \mathrm{C}\right)$ and humidity (85 to $95 \%$ ). Composites under accelerated aging (AA) and natural (NC) conditions (without UV irradiation) were subjected to biodegradation tests for 90 and 180 days. Thus, the samples were named as demonstrated in Table 2. The tests were performed in quadruplicate, as suggested by the biodegradation standard ASTM 160-12

Table 2: Codes for samples submitted to the biodegradation assay.

\begin{tabular}{c|c|c}
\hline Sample & $\begin{array}{c}\text { Days under } \\
\text { biodegradation }\end{array}$ & $\begin{array}{c}\text { Accelerated } \\
\text { aging }\end{array}$ \\
\hline NC-90BIO & 90 & No \\
\hline NC-180BIO & 180 & No \\
\hline AA-90BIO & 90 & Yes \\
\hline AA-180BIO & 180 & Yes \\
\hline
\end{tabular}

\subsubsection{Characterization}

UV-vis absorption spectra of the samples aged by UV radiation were recorded by Diffuse Reflectance Spectroscopy (DRS) on a spectrophotometer (Ocean Optics HR2000) coupled to an integrating sphere. The surface morphology was characterized by scanning electron microscopy (SEM) and optical microscopy (OM). The cross section of fractured samples by impact were also analyzed by SEM. The SEM analysis was performed using a JEOL JCM 5700 microscope operating at $5 \mathrm{kV}$ and SE mode. For this analysis, the samples were coated with a thin layer of gold using a Dentom Vacuum Sputter System DESK V. For optical microscopy, the samples were analyzed using a Carl Zeiss Axio Scope A.1 microscope. The mechanical properties were evaluated by tensile and flexural tests. The tensile properties were examined using an Instron Universal Test Machine model 3367. The instrument was operated at a crosshead speed of $3 \mathrm{~mm} / \mathrm{min}$, claw distance of $115 \mathrm{~mm}$, and load of $30 \mathrm{~N}$, according to the ASTM 638-03 standard. The values of the deformation at rupture, rupture stress, and modulus of elasticity were determined by this test. Flexural tests were also performed using an Instron Universal Test Machine model 3367 with three points and a distance between the supports of $64 \mathrm{~mm}$ at a displacement speed of $2 \mathrm{~mm} / \mathrm{min}$ and load of $5 \mathrm{~N}$. The equipment was operated according to the ISO 638-14 standard. During the flexure test, the specimens did not break and, so, the mechanical test was interrupted when $40 \mathrm{~mm}$ of deflection was reached. The modulus of elasticity and bending tensile properties were obtained under these conditions. The tension in flexion and modulus of elasticity in flexion were evaluated by this test. The tests were performed in quadruplicate and all the results for the mechanical properties were evaluated by the statistical analysis (Student's t-test with 95\% confidence interval) available on the SPSS statistics software, version 20. 


\section{RESULTS AND DISCUSSION}

\subsection{Optical properties}

According to Liu and co-workers [23], HDPE does not absorb light in the ultraviolet-visible region, as this polymer is a hydrocarbon consisting only of $\mathrm{C}-\mathrm{H}$ and $\mathrm{C}-\mathrm{C}$ bonds. However, some industries use ultraviolet stabilizers as additives in HDPE, such as the one used in this work (IA59U3), in order to prevent its photodegradation by ultraviolet radiation. Generally, these species act by absorbing the incident radiation and preventing it from reaching the polymer bulk. Thus, the absorbed energy is either converted into a less damaging form (such as heat) or the UV stabilizers reflect or scatter the radiation (as in the case of coatings) [24]. The UV-vis spectrum of the HDPE used in this work, as well as that of the HDPE-EG sample, are shown in Figures $2 \mathrm{a}$ and $2 \mathrm{~b}$ (spectrum named "initial" for both samples), respectively, which present two bands at 367 and $380 \mathrm{~nm}$ possibly associated with the presence of a UV stabilizer (its chemical composition was not provided by the manufacturer). After biodegradation tests in simulated soil, only the spectra of the samples irradiated with UV light (AA-90BIO and AA-180BIO for both samples) were found to lack such absorption bands. This result suggests that the previous treatment with UV light before the biodegradation essay was efficient for the degradation of these species on the surface of the samples.

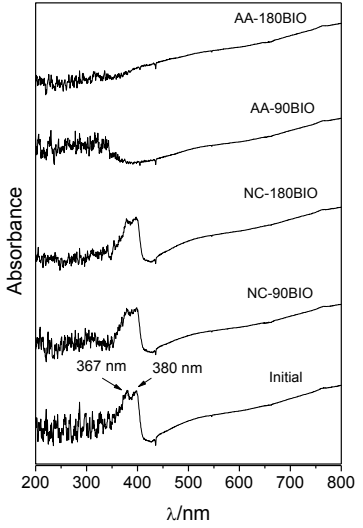

(a)

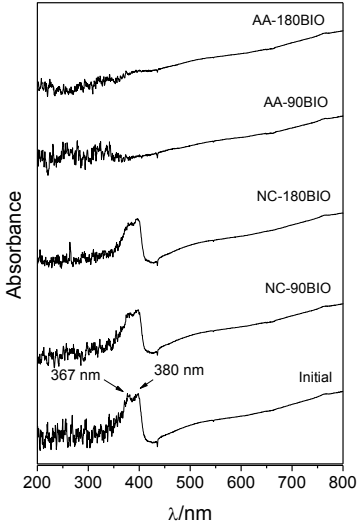

(b)

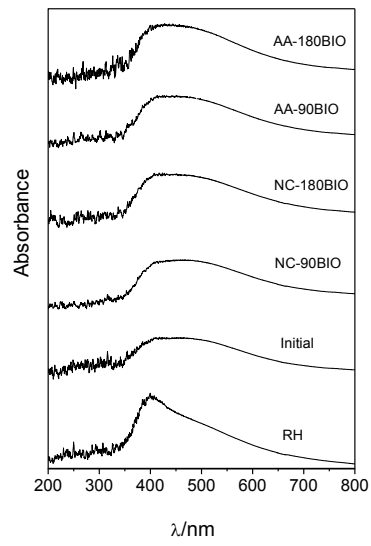

(c)

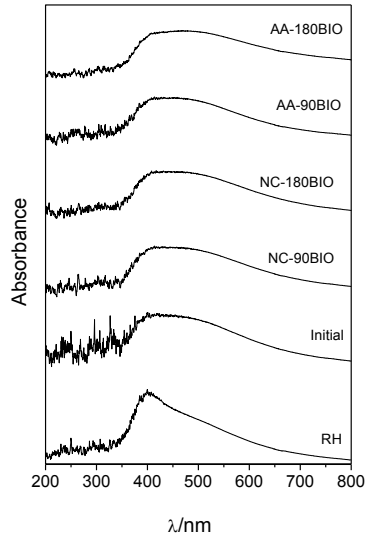

(d)

Figure 2: UV-vis spectra of samples (a) HDPE, (b) HDPE-EG, (c) HDPE-MA-RH, and (d) HDPE-MA-RH-EG before (initial) and after biodegradation testing under natural condition ( $\mathrm{NC}$, without a UV light treatment) and accelerated aging (AA, with a previous UV light treatment). In figures $\mathrm{c}$ and d, RH means rusk husk.

On the other hand, the samples prepared with RH show a broadband from 350 to $650 \mathrm{~nm}$, as observed in Figures 2c and 2d, attributed to the RH particles (see spectrum named "RH" in Figures 2c and 2d). Even after UV irradiation and biodegradation testing for 90 and 180 days (spectraNC-90BIO, NC-180BIO, AA$90 \mathrm{BIO}$ and AA-180BIO), this band remained in the spectra, probably due to the high concentration of RH in the composites (see Figures 1c and 1d). It is worth mentioning that the absorption of UV light is able to initiate photochemical reactions on sample surfaces, leading to the formation of aromatic and other free radicals than can then degrade lignin and photo-oxidize cellulose and hemi-cellulose [25].

\subsection{Morphological properties}

The combination of natural fibers and HDPE aims to modify some the mechanical properties of the polymer matrix, as well as confer biodegradability characteristics on this material. Through SEM measurements (see Figure 3), it was possible to visualize the interaction between the polymer matrix and the rice husk using maleic anhydride as the coupling agent. Figure 3a clearly shows the existence of microfibrils (red arrows) which are formed by the action of MA. The formation of these microfibrils is an important evidence that the natural fibers are satisfactorily adhered to the polymer matrix [26]. Additionally, it is noted in Figure $3 \mathrm{~b}$ that the $\mathrm{RH}$ particles are coated by the polymer, i.e., the rice fibers are homogeneously dispersed through the polymeric matrix, suggesting a favorable interaction between the components. Furthermore, each micro- 
fibril can be considered as a whiskers bundle due to the attachment via hydroxyl groups present in the cellulose chain to amorphous domains of the polymer matrix [26].

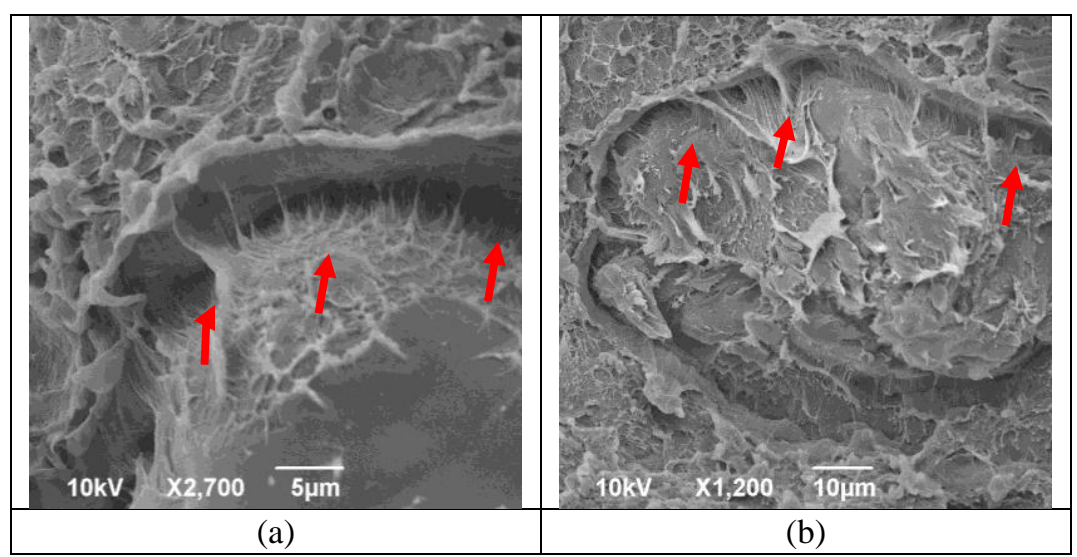

Figure 3: Cross section SEM images of samples (a) HDPE/MA/RH e (b) HDPE/MA/RH/EG. The red arrows show the formation of microfibrils between the rice husk/polymer matrix particle.

Scanning electron microscopy was used to analyze the changes in the surface topography of the samples under accelerated aging and natural conditions in simulated soil during 90 and 180 days. As shown in Figure 4, pure HDPE presents a smooth surface free of cracks, holes, or any other type of defect. Even after biodegradation, the polymer surface does not present any significant changes on its morphology, suggesting that no degradation has occurred. On the other hand, the HDPE-EG composite presents isolated cracks only after accelerated aging (UV weathering). As observed in Figures $2 a$ and $2 b$, no differences exist between the UV-vis spectra of the HDPE and HDPE-EG samples, since both of them absorb light in the UV range. Therefore, the SEM images suggest that the presence of the pro-oxidant promotes the mechanisms leading to photodegradation. The presence of cracks and grooves is associated with chain-scission phenomena occurring in HDPE due to photo-oxidation [27]. Chain-scission processes in HDPE would generate cracks between the surface and the inner layers of HDPE.

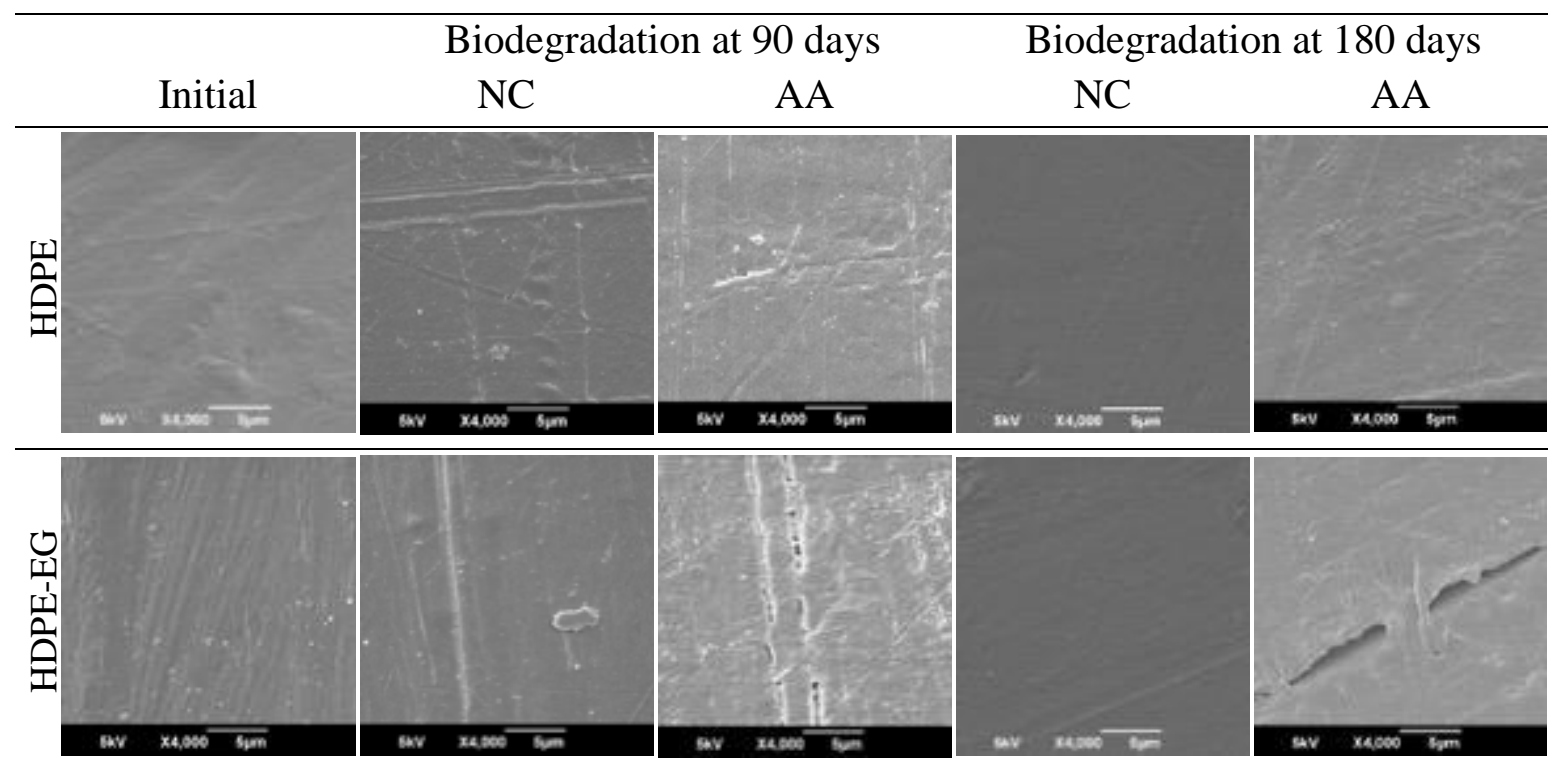



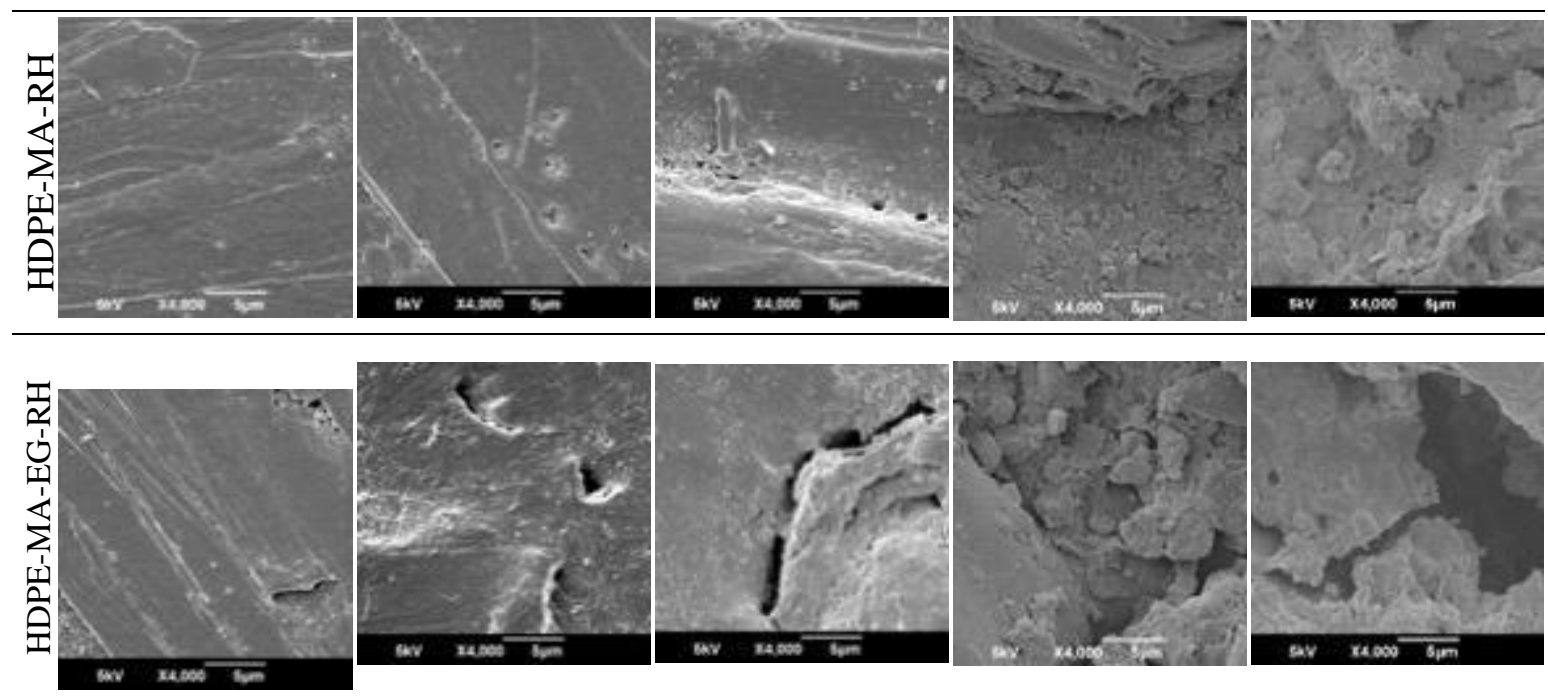

Figure 4: SEM images of samples HDPE, HDPE-EG, HDPE-MA-RH, and HDPE-MA-RH-EG before (initial) and after 90 and 180 days under accelerated aging and biodegradation.

In contrast, greater evidence of biodegradation was found in the HDPE-MA-RH and HDPE-MA-EGRH samples. These compositions present cracks distributed across their surface, especially those subjected to UV irradiation. According to Khalil et al., the degree of photodegradation of cellulose-based materials largely depends on their ability to absorb UV light [25]. Thus, as observed in the previous section, the UV-vis spectra of those samples present higher absorption in the UV region, resulting in surface degradation of the composites and, consequently, inducing visible changes in the surface, such as discoloration and the formation of cracks. The cracks resulting from the propagation of micro cracks and the formation of slits on the surface illustrate the effects of adding an organic pro-oxidant to these samples.

According to the literature, during exposure to UV radiation, polymers such as polyolefins bound to pro-oxidants undergo cleavage predominantly of the weaker bonds of the polymer (i.e., those with lower binding energies). This leads to the formation of free radicals able to react with atmospheric air and cause the oxidation of the polymer [28]. Such photo-oxidation process occurs in the amorphous regions of polymers due to their higher oxygen permeability [29]. The cracks observed may be the result of thermal stress or residual stress on the polymer surface generated upon exposure to the accelerated aging.

In addition, optical microscopy measurements were performed to evaluate the surface and morphological changes of the polymers. As seen in Figure 5, the surface of the HDPE-MA-RH and HDPE-MA-RH-EG composites exhibits greater signs of degradation. The larger number of holes/cracks in these samples compared to those of the bare HDPE and HDPE-EG materials suggests that the degradation is initiated by the rice husk particles and that the fiber is the initial point of degradation in these composites. The rice husk particles are very susceptible to the action of accelerated aging and microorganisms, serving as a "gateway" for abiotic degradation. As reported by others, the exposure of fibers to sunlight of wavelength greater than $290 \mathrm{~nm}$ in the presence of oxygen results in the rapid deterioration of these materials, as they become extremely fragile and susceptible to degradation after small exposure periods [30]. On the other hand, the HDPE and HDPEEG materials exhibit slight surface changes when subjected to accelerated aging by UV radiation, in which the presence of "bubbles" on their surface is detected. 


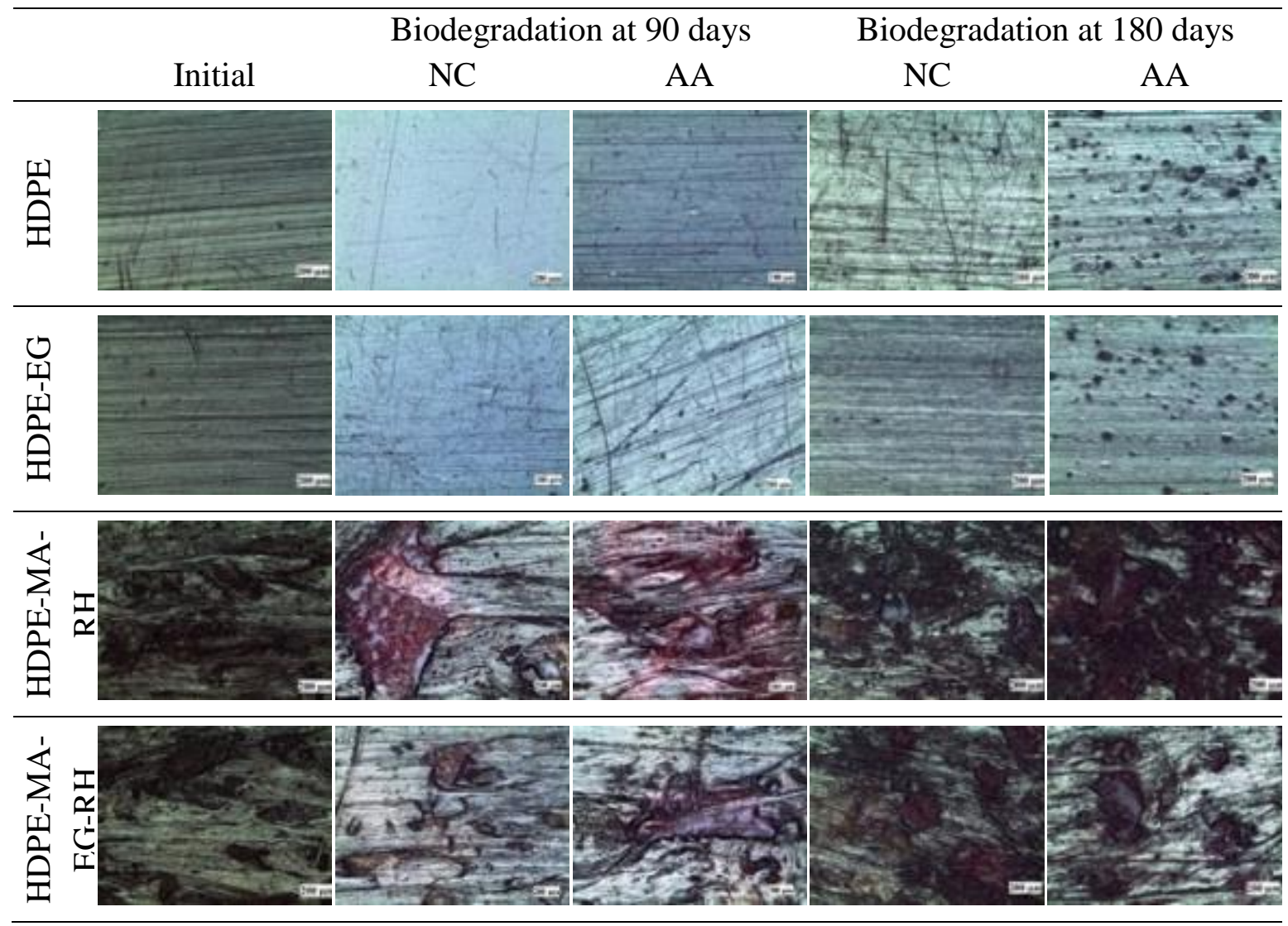

Figure 5: optical microscopy images of samples HDPE, HDPE-EG, HDPE-MA-RH, and HDPE-MA-RH-EG before (initial) and after 90 and 180 days under accelerated aging and biodegradation.

\subsection{Mechanical properties}

The mechanical tensile and flexural properties were studied in order to determine the influence of the prooxidant in the composites after the biodegradation tests. It is worth noting that the compositions containing only HDPE and HDPE-EG did not break during the tensile tests, which were interrupted at $200 \%$ deformation. Thus, for such compositions, data on the deformation at rupture, rupture stress, and modulus of elasticity were obtained under these conditions. Table 3 shows the results concerning the deformation at rupture for the composites with and without EG under accelerated aging (AA), irradiated with UV light, and natural conditions (NC), without UV irradiation, after 90 and 180 days of biodegradation, denominated BIO. No statistical differences were determined between the HDPE and HDPE-EG compositions under both natural and accelerated aging after 90 and 180 days. A similar behavior has been reported in the literature for polyethylene films containing pro-oxidant agents $[31,32]$.

Table 3: Deformation at rupture of samples HDPE, HDPE-EG, HDPE-MA-RH, and HDPE-MA-RH-EG before (initial) and after biodegradation testing under natural condition ( $\mathrm{NC}$, without a UV light treatment) and accelerated aging (AA, with a previous UV light treatment).

\begin{tabular}{c|c|c|c|c}
\hline Condition/Sample & HDPE & HDPE-EG & HDPE-MA-RH & HDPE-MA-RH-EG \\
\hline Inicial & 200 & 200 & $14.13 \pm 0.67$ & $15,63 \pm 2.64$ \\
\hline NC-90BIO & 200 & 200 & $17.38 \pm 1.73$ & $14,84 \pm 1.59$ \\
\hline AA-90BIO & 200 & 200 & $16.93 \pm 2.63$ & $12,7 \pm 1.05$ \\
\hline NC-180BIO & 200 & 200 & $16 \pm 1.62$ & $13,11 \pm 1.08$ \\
\hline AA-180BIO & 200 & 200 & $14.69 \pm 2.23$ & $13,05 \pm 1.16$ \\
\hline
\end{tabular}


On the other hand, the reduction of the deformation at rupture of the HDPE-MA-RH and HDPE-MAEG-RH composites is attributed to the presence of rice husk particles that render the samples less ductile owing to a reduction of the motility of the polyethylene chains [33]. Moreover, it was confirmed that the HDPEMA-EG-RH sample showed reduced deformation at rupture when compared to sample HDPE-MA-RH, with statistical differences when subjected to accelerated aging and 90 days of biodegradation, thus demonstrating the effect of UV radiation on the composites under study. Moreover, the presence of EG favors the abiotic degradation as it facilitates the cleavage of polyethylene chains, resulting in smaller chains to be digested by the microorganisms during the biodegradation stage [5,34].

The same behavior was found when samples HDPE-MA-RH and HDPE-MA-EG-RH were compared, displaying statistical differences when subjected to natural conditions and 180 days of biodegradation. Although these composites were not aged by UV radiation, the time of exposure to the simulated soil demonstrates the effect of the organic pro-oxidant and the action of microorganisms in the decomposition of $\mathrm{RH}$ particles. The microorganisms present in the soil act directly on the rice husk particles and the amorphous portion of the polymer, facilitating the entry of water/moisture and enzymes and leading to enhanced biodegradation [35].

The modulus of elasticity after UV-accelerated aging, shown in Table 4, was also evaluated for the different composites. Statistically, a significant difference in this mechanical property was observed for the pure HDPE and HDPE-EG compositions compared to the HDPE-MA-RH and HDPE-MA-RH-EG samples. The presence of rice husk particles seems to induce an increase in the elasticity modulus, favoring the stiffness of the composites. On the other hand, UV light irradiation was not found to have a significant influence on the HDPE and HDPE-EG samples in relation to the exposure time to the simulated soil. The same behavior was observed when the HDPE-MA-RH and HDPE-MA-RH-EG samples were compared, indicating that the pro-oxidant does not have a significant influence on the modulus of elasticity of these compositions.

Table 4: Modulus of elasticity of samples HDPE, HDPE-EG, HDPE-MA-RH, and HDPE-MA-RH-EG before (initial) and after biodegradation testing under natural condition ( $\mathrm{NC}$, without a UV light treatment) and accelerated aging (AA, with a previous UV light treatment).

\begin{tabular}{|c|c|c|c|c|}
\hline $\begin{array}{l}\text { Condi- } \\
\text { tion/Sample }\end{array}$ & HDPE & HDPE-EG & RH HDPE-MA- & $\begin{array}{l}\text { HDPE-MA- } \\
\text { RH-EG }\end{array}$ \\
\hline Inicial & $1175.19 \pm 5$ & $1088.54 \pm 39$ & $1730.53 \pm 12$ & $1657.68 \pm 188$ \\
\hline NC-90BIO & $1149.18 \pm 5$ & $1089.98 \pm 3$ & $1671.41 \pm 75$ & $1604.30 \pm 60.5$ \\
\hline AA-90BIO & $1197.77 \pm 6$ & $1105.1 \pm 64$ & $1597.87 \pm 12$ & $1556.79 \pm 66.9$ \\
\hline NC-180BIO & $1141.63 \pm 3$ & $\begin{array}{ll}5.02 & 1061.86 \pm 14\end{array}$ & $1598.50 \pm 85$ & $1545.48 \pm 11.5$ \\
\hline AA-180BIO & $1132.22 \pm 8$ & $1076.21 \pm 73$ & $1559.60 \pm 17$ & $1538.95 \pm 21.3$ \\
\hline
\end{tabular}

The tensile stress, shown in Table 5, was also evaluated for the samples subjected to biodegradation tests. A significant difference was observed between the composites upon addition of rice husk particles, that is, differences were observed between the HDPE and HDPE-EG samples and HDPE-MA-RH and HDPEMA-EG-RH composites. The tensile stress data suggest that the organic pro-oxidant does not significantly influence this mechanical variable, as the value for the HDPE-MA-EG-RH sample was found to be independent of the time of exposure to the simulated soil. According to Koutny and co-workers [36], the action of the pro-oxidant occurs exclusively in the amorphous regions of the polymer, while the crystalline regions remain intact, and thus the mechanical properties are not influenced due to the selective cleavage of bonds in the amorphous regions. 
Table 5: Tensile stress of samples HDPE, HDPE-EG, HDPE-MA-RH, and HDPE-MA-RH-EG before (initial) and after biodegradation testing under natural condition (NC, without a UV light treatment) and accelerated aging (AA, with a previous UV light treatment).

\begin{tabular}{c|cc|cc|c|c}
\hline $\begin{array}{c}\text { Condi- } \\
\text { tion/Sample }\end{array}$ & \multicolumn{2}{|c|}{ HDPE } & & HDPE-EG & $\begin{array}{c}\text { HDPE- } \\
\text { MA-RH }\end{array}$ & EG \\
\hline Inicial & 9 & $12.69 \pm 0.0$ & 1 & $12.26 \pm 0.2$ & $6.4 \pm 0.25$ & $5.9 \pm 0.3$ \\
\hline NC-90BIO & 7 & $12.50 \pm 0.2$ & & $12.16 \pm 0.6$ & $5.58 \pm 2.24$ & $6.55 \pm 0.72$ \\
\hline AA-90BIO & 7 & $12.56 \pm 0.5$ & 6 & $12.03 \pm 1.0$ & $5.95 \pm 0.52$ & $6.87 \pm 0.29$ \\
\hline $\begin{array}{c}\text { NC- } \\
180 \mathrm{BIO}\end{array}$ & 5 & $12.28 \pm 0.1$ & 4 & $12.31 \pm 1.3$ & $5.35 \pm 0.83$ & $5.85 \pm 0.43$ \\
\hline $\begin{array}{c}\text { AA- } \\
180 \mathrm{BIO}\end{array}$ & 2 & $11.77 \pm 1.1$ & & $11.93 \pm 1.0$ & $6.85 \pm 0.47$ & $6.37 \pm 0.41$ \\
\hline
\end{tabular}

Regarding the bending stress tests, it was confirmed that the HDPE-MA-RH and HDPE-MA-EG-RH samples statistically differ under accelerated aging conditions and 90 days of biodegradation (AC-90D), as shown in Table 6. This behavior can be explained by the incidence of UV radiation upon accelerated aging, favoring chain scission and, consequently, resulting in a reduction of this parameter [37]. Moreover, for all conditions and biodegradation times, the HDPE and HDPE-EG samples were found to differ statistically from the HDPE-MA-RH and HDPE-MA-EG-RH composites due to the presence of rice husk particles, as this material is very efficient for reinforcement. Thus, the reinforcement (rice husk) is homogeneously distributed in the continuous phase (polymer matrix), thereby increasing the mechanical strength of the composites [11].

Table 6: Tensile stress in flexure of samples HDPE, HDPE-EG, HDPE-MA-RH, and HDPE-MA-RH-EG before (initial) and after biodegradation testing under natural condition (NC, without a UV light treatment) and accelerated aging (AA, with a previous UV light treatment).

\begin{tabular}{|c|c|c|c|c|}
\hline $\begin{array}{l}\text { Condi- } \\
\text { tion/Sample }\end{array}$ & HDPE & HDPE-EG & $\begin{array}{l}\text { HDPE- } \\
\text { MA-RH }\end{array}$ & EG HDPE-MA-RH- \\
\hline Inicial & $7.89 \pm 0.33$ & $7.76 \pm 0.16$ & $11.21 \pm 0.2$ & $11.01 \pm 0.25$ \\
\hline NC-90BIO & $19.46 \pm 0.4$ & $18.68 \pm 0.5$ & $26.22 \pm 0.2$ & $25.75 \pm 0.24$ \\
\hline AA-90BIO & $20.60 \pm 0.5$ & $19.97 \pm 0.6$ & $29.67 \pm 0.3$ & $28.47 \pm 0.55$ \\
\hline $\begin{array}{l}\text { NC- } \\
180 \mathrm{BIO}\end{array}$ & $20.39 \pm 0.3$ & $17.26 \pm 0.7$ & $24.77 \pm 1.8$ & $25.93 \pm 0.67$ \\
\hline $\begin{array}{l}\text { AA- } \\
180 \mathrm{BIO}\end{array}$ & $20.40 \pm 0.6$ & $20.15 \pm 0.5$ & $27.83 \pm 0.3$ & $27.12 \pm 0.54$ \\
\hline
\end{tabular}

Finally, the flexural modulus of elasticity was studied for the composites after biodegradation. As observed in Table 7, no significant differences between the HDPE, HDPE-EG, HDPE-MA-RH, and HDPEMA-EG-RH composites were found for all the conditions studied, as determined by the t-test. However, the modulus of elasticity was higher for the composites prepared in the presence of rice husk particles for the initial condition (before the biodegradation essay). The good adhesion between the rice husk particles and the polymeric matrix favors the homogeneous distribution of forces, increasing the stiffness and thus the modulus of elasticity in flexion [33,11,12]. After the biodegradation essay, it is observed that the flexural modulus of elasticity is higher for the composites under different conditions in relation to their initial condition. The 
increase of modulus of elasticity in flexion may be related to the breaking of the polyethylene chain, resulting in the formation of smaller crystallites and, consequently, in the increase of the polymer crystallinity. Thus, there is a decrease in the mobility of the polymer chains, increasing the stiffness of the composite and, therefore, the flexural modulus of elasticity.

Table 7: Modulus of the elasticity in flexure for samples HDPE, HDPE-EG, HDPE-MA-RH, and HDPE-MA-RH-EG before (initial) and after biodegradation testing under natural condition (NC, without a UV light treatment) and accelerated aging (AA, with a previous UV light treatment).

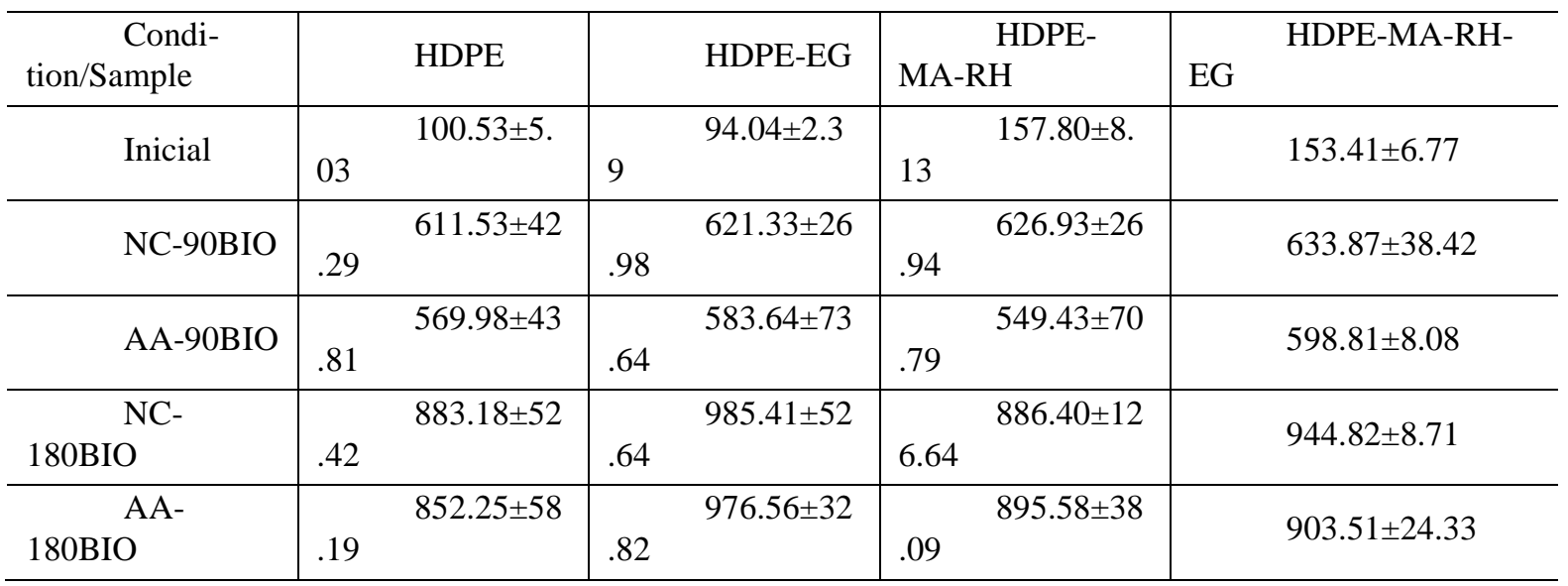

\section{CONCLUSION}

Overall, the results have shown that $\mathrm{RH}$, a waste from agriculture, can be used as reinforcing particles for HDPE processing. Although the HDPE used in this work presents an antioxidant agent and a UV light stabilizing additive, HDPE-MA-RH and HDPE-MA-RH-EG samples presented a greater degree of biodegradation upon previous irradiation with UVA light, as suggested by the SEM and OM images. This behavior may be related to their UV-vis spectral features, which are characterized by a broadband from 350 to $650 \mathrm{~nm}$. Such high light absorption may initiate the degradation process even before biodegradation begins. Finally, the mechanical tensile and flexural properties, such as the deformation at rupture, modulus of elasticity, tensile stress, tensile stress in flexure, and modulus of elasticity in flexure exhibited significant changes upon introduction of RH particles in the HDPE matrix, indicating that the RH particles were homogeneously dispersed throughout the polymer matrix. Finally, it is possible to state that the sample HDPE-MA-RH-EG presented compatible features for application as plastic materials in agriculture, especially for the design of seedling tubes, since it shows a long-term biodegradation behavior, without loss of mechanical properties during application.

\section{ACKNOWLEDGMENT}

This work was financed by FAPITEC, CNPq and CAPES. G.R.S.A. acknowledges the support from CAPES (PNPD/CAPES).The authors would like to thank Everton Souza (in memoriam) for his technical contributions.

\section{BIBLIOGRAPHY}

[1] BRIASSOULIS, D., MISTRIOTIS, A., ELEFTHERAKIS, D., "Mechanical behaviour and properties of agricultural nets-Part I: Testing methods for agricultural nets”, Polymer Testing, v. 26, n. 6, pp. 822-832, Set. 2007

[2] BRODHAGEN, M., GOLDBERGER, J.R., HAYES, D.G., et al., "Policy considerations for limiting unintended residual plastic in agricultural soils”, Environmental Science \& Policy, v. 69, pp. 81-84, Mar. 2017.

[3] VOX, G., LOISI, R.V., BLANCO, I., et al., "Mapping of Agriculture Plastic Waste", Agriculture and Agricultural Science Procedia, v. 8, pp. 583-591, Jan. 2016. 
[4] LANORTE, A., DE SANTIS, F., NOLÈ, G., et al., "Agricultural plastic waste spatial estimation by Landsat 8 satellite images", Computers and Electronics in Agriculture, v. 141, pp. 35-45, Set. 2017.

[5] JAKUBOWICZ, I., "Evaluation of degradability of biodegradable polyethylene (PE)", Polymer Degradation and Stability, v. 80, n. 1, pp. 39-43, Jan. 2003.

[6] FÁVARO, S. L.,GANZERLI, T. A.,CARVALHO NETO, A. G. V., et al.,“Chemical, morphological and mechanical analysis of sisal fiber-reinforced recycled high-density polyethylene composites", Express Polymer Letters, v. 4, pp. 465-473, Mar. 2010.

[7] INÁCIO, A.L.N., NONATO, R.C., BONSE, B.C., "Recycled PP/EPDM/talc reinforced with bamboo fiber: Assessment of fiber and compatibilizer content on properties using factorial design", Polymer Testing, v. 61, pp. 214-222, Ago. 2017.

[8] ALAMRI, H., LOW, I.M., "Mechanical properties and water absorption behaviour of recycled cellulose fibre reinforced epoxy composites", Polymer Testing, v. 31, n. 5, pp. 620-628, Ago. 2012.

[9] FERNANDES, E.M., CORRELO, V.M., MANO, J.F., et al., "Novel cork-polymer composites reinforced with short natural coconut fibres: Effect of fibre loading and coupling agent addition", Composites Science and Technology, v. 78, pp. 56-62, Abr. 2013.

[10] DIKOBE, D.G., LUYT, A.S., "Thermal and mechanical properties of PP/HDPE/wood powder and MAPP/HDPE/wood powder polymer blend composites", Thermochimica Acta, v. 654, pp. 40-50, Ago. 2017.

[11] TONG, J.Y., ROYAN, N.R.R., NG, Y.C., et al., "Study of the Mechanical and Morphology Properties of Recycled HDPE Composite Using Rice Husk Filler", Advances in Materials Science and Engineering, v. 2014, pp. 1-6, Feb. 2014.

[12] ARRAKHIZ, F.Z., EL ACHABY, M., MALHA, M., et al., "Mechanical and thermal properties of natural fibers reinforced polymer composites: Doum/low density polyethylene", Materials \& Design, v. 43, pp. 200-205, Jan. 2013.

[13] BILAL, A., LIN, R.J.T., JAYARAMAN, K., ZHANG, C., "Evaluation of Mechanical Properties on Rice Husk and Expanded Rice Husk Filled Polyethylene Composites", International Journal of the Institute of Materials Malaysia, v. 1, pp. 165-170, Jul. 2014.

[14] ARJMANDI, R., HASSAN, A., MAJEED, K., et al., "Rice Husk Filled Polymer Composites", International Journal of Polymer Science, v. 2015, pp. 1-32, Mai. 2015.

[15] AYSWARYA, E.P., VIDYA FRANCIS, K.F., RENJU, V.S., et al., "Rice husk ash - A valuable reinforcement for high density polyethylene", Materials \& Design, v. 41, pp. 1-7, Out. 2012.

[16] ORTIZ, A.V., TEIXEIRA, J.G., GOMES, M.G., et al., "Preparation and characterization of electronbeam treated HDPE composites reinforced with rice husk ash and Brazilian clay", Applied Surface Science, v. 310, pp. 331-335, Ago. 2014.

[17] FÁVARO, S.L., LOPES, M.S., VIEIRA DE CARVALHO NETO, A.G., et al., "Chemical, morphological, and mechanical analysis of rice husk/post-consumer polyethylene composites", Composites Part A: Applied Science and Manufacturing, v. 41, n. 1, pp. 154-160, Jan. 2010.

[18] WANG, W., YANG, X., BU, F., et al., "Properties of rice husk-HDPE composites after exposure to thermo-treatment", Polymer Composites, v. 35, n. 11, pp. 2180-2186, Nov. 2014.

[19] ZHAO, Q., ZHANG, B., QUAN, H., et al., "Flame retardancy of rice husk-filled high-density polyethylene ecocomposites", Composites Science and Technology, v. 69, n. 15, pp. 2675-2681, Dez. 2009.

[20] AREMU, M.O., OKO, O.J., ANDREW, C., "Ground Water and River Quality Assessment for Some Heavy Metals and Physicochemical Parameters in Wukari Town, Taraba State, Nigeria", International Journal of Sciences, v. 6, pp. 73-80, May 2017.

[21] SAMAL, S.K., FERNANDES, E.G., CORTI, A., et al., "Bio-based Polyethylene-Lignin Composites Containing a Pro-oxidant/Pro-degradant Additive: Preparation and Characterization", Journal of Polymers and the Environment, v. 22, n. 1, pp. 58-68, Mar. 2014.

[22] MONTAGNA, L.S., FORTE, M.M. DE C., SANTANA, R.M.C., "Study on the accelerated biodegradation of PP modified with an organic pro-degradant additive", Journal of Applied Polymer Science, v. 131, n. 22, Jun. 2014.

[23] LIU, X., YU, L., XIE, F., et al., "New evidences of accelerating degradation of polyethylene by starch", Journal of Applied Polymer Science, v. 130, n. 4, pp. 2282-2287, Nov. 2013.

[24] YOUSIF, E., HADDAD, R., "Photodegradation and photostabilization of polymers, especially polysty- 
rene: review", Springer Plus, v. 2, pp. 398, Ago. 2013.

[25] KHALIL, H.P.S.A.,TYE, Y.Y.,SAURABH, C.K., et al., "Biodegradable polymer films from seaweed polysaccharides: A review on cellulose as a reinforcement material", Express Polymer Letters, v. 11, pp. 244265, Nov. 2017.

[26] ROSA, M.F., MEDEIROS, E.S., MALMONGE, J.A., et al., "Cellulose nanowhiskers from coconut husk fibers: Effect of preparation conditions on their thermal and morphological behavior", Carbohydrate Polymers, v. 8, pp. 83-92, Feb. 2010.

[27] BEG, M.D.H., PICKERING, K.L., "Accelerated weathering of unbleached and bleached Kraft wood fibre reinforced polypropylene composites", Polymer Degradation and Stability, v. 93, n. 10, pp. 1939-1946, Out. 2008 .

[28] OJEDA, T., FREITAS, A., BIRCK, K., et al., "Degradability of linear polyolefins under natural weathering", Polymer Degradation and Stability, v. 96, n. 4, pp. 703-707, Abr. 2011.

[29] BORSOI, C., BERWIG, K.H., SCIENZA, L.C., et al., "The photodegradation and biodegradation of rEPS/curaua fiber composites", Polymer Composites, v. 34, n. 6, pp. 967-977, Jun. 2013.

[30] CARLSSON, D.J., WILES, D.M., "The Photooxidative Degradation of Polypropylene. Part I. Photooxidation and Photoinitiation Processes", Journal of Macromolecular Science, Part C, v. 14, n. 1, pp. 65-106, Jan. 1976.

[31] KYRIKOU, I., BRIASSOULIS, D., HISKAKIS, M., et al., "Analysis of photo-chemical degradation behaviour of polyethylene mulching film with pro-oxidants", Polymer Degradation and Stability, v. 96, n. 12, pp. 2237-2252, Dez. 2011.

[32] BENÍTEZ, A., SÁNCHEZ, J.J., ARNAL, M.L., et al., "Monitoring abiotic degradation of branched polyethylenes formulated with pro-oxidants through different mechanical tests", Polymer Degradation and Stability, v. 98, n. 9, pp. 1705-1716, Set. 2013.

[33] MAJEED, K., HASSAN, A., BAKAR, A.A., "Influence of maleic anhydride-grafted polyethylene compatibiliser on the tensile, oxygen barrier and thermal properties of rice husk and nanoclay-filled low-density polyethylene composite films", Journal of Plastic Film \& Sheeting, v. 30, n. 2, pp. 120-140, Abr. 2014.

[34] CORTI, A., MUNIYASAMY, S., VITALI, M., et al., "Oxidation and biodegradation of polyethylene films containing pro-oxidant additives: Synergistic effects of sunlight exposure, thermal aging and fungal biodegradation", Polymer Degradation and Stability, v. 95, n. 6, pp. 1106-1114, Jun. 2010.

[35] PATWARY, F., MITTAL, V., "Degradable polyethylene nanocomposites with silica, silicate and thermally reduced graphene using oxo-degradable pro-oxidant", Heliyon, v. 1, n. 4, pp. e00050,Dez. 2015.

[36] KOUTNY, M., SANCELME, M., DABIN, C., et al., "Acquired biodegradability of polyethylenes containing pro-oxidant additives", Polymer Degradation and Stability, v. 91, n. 7, pp. 1495-1503, Jul. 2006.

[37] PORTILLO, F., YASHCHUK, O., HERMIDA, É., "Evaluation of the rate of abiotic and biotic degradation of oxo-degradable polyethylene", Polymer Testing, v. 53, pp. 58-69, Ago. 2016. 